\title{
Synthesis and antibacterial evaluation of new azo-pyrimidine derivatives
}

\author{
Mohamed A. Abdelgawad ${ }^{1,2^{*}}$ \\ ${ }^{1}$ Department of Pharmaceutical Chemistry, College of Pharmacy, Jouf University, Sakaka, Aljouf, Saudi Arabia. \\ ${ }^{2}$ Department of Pharmaceutical Organic Chemistry, Faculty of Pharmacy, Beni-Suef University, Beni-Suef, Egypt.
}

\begin{tabular}{l}
\hline ARTICLE INFO \\
\hline Received on: 25/08/2018 \\
Accepted on: 23/09/2018 \\
Available online: 03/03/2019 \\
\\
Key words: \\
Antibacterial, pyrimidine, \\
diethyl malonate, \\
pyrimidinone.
\end{tabular}

\begin{abstract}
The synthesis of potent antibacterial agents, free from side effects and resistant to bacterial enzymes, is the main objective for drug designers. Also, the multi-target drugs have an important role in advanced drug synthesis. The azo-malonate compounds II a \& b were prepared from the diazo coupling reaction of aniline derivatives with the acidic methylene group of diethyl malonate. The new azo-malonate derivatives II a-c were reacted with urea or thiourea in the presence of sodium ethoxide, afforded the target new azo-pyrimidine compounds III a \& $b$ and IV a $\&$ b. The structure of the new compounds was elucidated by using NMR, IR, mass spectroscopy, and elemental analysis. The minimum inhibitory concentration of new azo-compounds III a \& b and IV a \& b was evaluated for their antibacterial activity. Two new synthesized azo-compounds showed weak (III b) to strong (IV b) antibacterial activity. The molecular operating environment docking program was used for the prediction of the compound IV b action mechanism.
\end{abstract}

\section{INTRODUCTION}

The resistance of microorganisms to antibiotics is a critical and dangerous medical problem (Koca et al., 2005). The discovery of new synthetic antibacterial agent effective against resistant microorganisms is important for medicinal chemists. Despite the discovery of many natural and synthetic antibiotics, the innovation of new antibacterial will help in solving the emergence of the microorganisms' resistance problem (Mallikarjunaswamya et al., 2017).

The pyrimidine ring is the main component of DNA and RNA bases and as a result of that pyrimidine natural derivatives have important physiological activities.

The synthetic pyrimidine-containing compounds possess interesting and varied biological activities like cytotoxicity, antifungal or antibacterial activities (Awadallah et al., 2013;

\footnotetext{
*Corresponding Author

Mohamed A. Abdelgawad, Department of Pharmaceutical Chemistry,

College of Pharmacy, Jouf University, Sakaka, Saudi Arabia.

E-mail: mohamedabdelwahab976@yahoo.com; mhmdgwd @ ju.edu.sa
}

This article was presented at the 5th Euro-Mediterranean Conference and Expo on Life Sciences, Pharma and Biomedicine (BioNat-V), Limassol, Cyprus.
Gadhaveb et al., 2015; Saundane et al., 2013). Upon literature survey, it was found that the compounds having heterocyclic moieties within its scaffolds were reported to have different biological importance (Bansal et al., 2014; Bakulev et al., 2003; Rahmi et al., 2010; Riyadh et al., 2010; Sayed et al., 2007). Also, the substituted-phenylpyrimidinone (1) was known to possess potent antimicrobial activity (Abdelgawad et al., 2017; Belal and Abdelgawad, 2017; Gawad et al., 2012; Mandha et al., 2012).

Drugs containing substituted-pyrimidine, Iclaprim (2) is a potent dihydrofolate inhibitor which is found to be active against vancomycin and methicillin-resistant strain (Schneider et al., 2003; Vinita et al., 2014). The well-known antibacterial, trimethoprim (3) and pyrimethamine (4) are selective dihydrofolate reductase inhibitors (Cheng and Roth, 1982; Vinita et al., 2014; Zaini et al., 2017). The trisubstituted-pyrimidine compound (5) is found to be an effective antibacterial agent (Vinita et al., 2014) (Fig. 1A).

The incorporation of substituted-aniline with pyrimidine through azo-group in one scaffold may had an important role in enhancing the antibacterial activity or cancelling the effect of bacterial enzymes which are responsible for antibiotics destruction, for the new synthesized azo-compounds. Also, multi-targets synthesized new azo-compounds with a complicated structure 
(A)

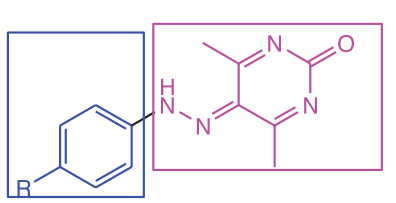

1
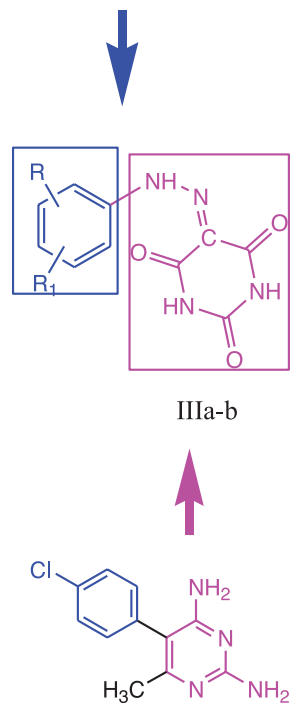

4

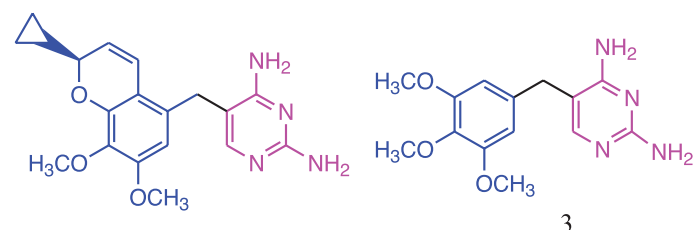

2
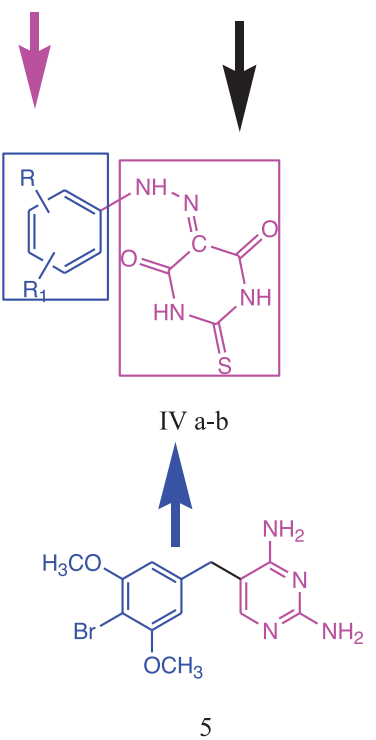

5

(B)<smiles>[R]c1cccc(NN=C(C(=O)OCC)C(=O)OCC)c1C(=O)OCC</smiles>

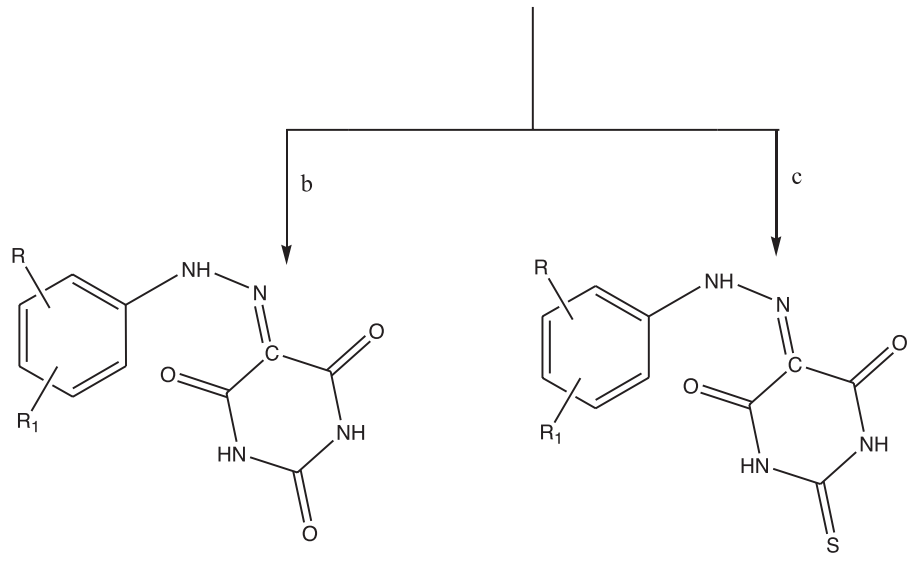

IIIa\&b IV a\&b

$\mathrm{R}$

R1

a $\quad 3-\mathrm{OCH}_{3} \quad 4-\mathrm{OCH}_{3}$

b $\quad 3-\mathrm{Cl} \quad 5-\mathrm{Cl}$

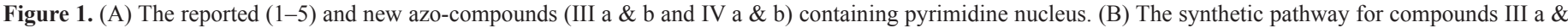
$\mathrm{b}$ and IV $\mathrm{a} \& \mathrm{~b}$. 
that may affect several biological targets of bacteria which are important for the bacteria life cycle. This leads to pronounced antibacterial activity.

In the view of the previously mentioned findings, it is very interesting to synthesis substituted phenylhydrazones bearing pyrimidine III a \& $\mathrm{b}$ and IV a \& $\mathrm{b}$ and screen for their antibacterial activity. Also, the synthesis of new pyrimidines III a \& b and IV a \& b may open the gate for a new antibacterial agent with potent activity against resistant microorganisms (Fig. 1B).

\section{MATERIAL AND METHODS}

\section{Chemistry}

Melting points are uncorrected. NMR, IR, mass spectroscopy, and elemental analysis were used for elucidation of the chemical structure of the new compounds. The methods and instrumentations are according to reported methods (Abdelgawad et al., 2017). Compounds II b was synthesized according to the literature procedure (Etman et al., 2015; Kalluraya et al., 2004).

\section{2-[(3,4-Dimethoxy-phenyl)-hydrazono]-malonic acid diethyl ester (II a)}

The ice cool solution of 3,4-dimethoxyaniline $(0.01 \mathrm{~mol})$ in $\mathrm{HCl}(10 \%, 10 \mathrm{ml})$ and sodium nitrite solution $(0.01 \mathrm{~mol}, 5 \mathrm{ml}$ water $)$ was stirred. The diazonium solution was added to the cooled stirred solution of diethyl malonate $(0.01 \mathrm{~mol})$ and sodium acetate $(0.01$ $\mathrm{mol})$ in aqueous ethanol $(50 \%, 20 \mathrm{ml})$. The mixture was stirred for 4 hours in ice bath. The separated solid was filtered and crystallized from ethanol $(95 \%)$. Yellow crystal $(90 \%)$; mp $145^{\circ} \mathrm{C}-147^{\circ} \mathrm{C}$; IR (film) 3,280 (NH), 2,915 (CH, aliphatic), 1,730, 1,715 (broad band, $\mathrm{C}=\mathrm{O}) \mathrm{cm}^{-1} ;{ }^{1} \mathrm{H}$ NMR (DMSO- $\left.d_{6}\right) \delta 1.24-1.29\left(\mathrm{~m}, 6 \mathrm{H}, \mathrm{CH}_{2} \mathrm{CH}_{3}\right), 3.74$ (s, 3H, 3- $\left.\mathrm{OCH}_{3}\right), 3.77\left(\mathrm{~s}, 3 \mathrm{H} .4 \mathrm{OCH}_{3}\right), 4.20-4.30\left(\mathrm{~m}, 4 \mathrm{H}, \mathrm{CH}_{2} \mathrm{CH}_{3}\right)$, 6.96-6.98 (m, 2H, phenyl H-5,6), 7.13 (s, 1H, phenyl H-2), 12.18 (s, $1 \mathrm{H}, \mathrm{NH}-\mathrm{N}=\mathrm{C}$ ); Anal. Calcd for $\mathrm{C}_{15} \mathrm{H}_{20} \mathrm{~N}_{2} \mathrm{O}_{6}: \mathrm{C}, 55.55 ; \mathrm{H}, 6.22 ; \mathrm{N}$, 8.64, Found: C, 55.50; H, 6.20; N, 8.60.

\section{General procedure for synthesis of compound III a \& b}

The sodium ethoxide solution (sodium, $0.03 \mathrm{~mol}$, absolute ethanol $20 \mathrm{ml}$ ) was added to a solution of compound II a/II b (0.01 mol, absolute ethanol $20 \mathrm{ml})$. The mixture of urea solution $(0.01 \mathrm{~mol}$, absolute ethanol $10.0 \mathrm{ml})$ and the reaction mixture were heated under reflux for 4 hours. The hot water (40 $\mathrm{ml}$ ) was added to the reaction mixture, then enough amount of $\mathrm{HCl}$ was added until the reaction mixture became acidic to litmus paper and kept in the refrigerator for 2 hours. The precipitate was filtered, dried, and crystallized from ethanol to afford compounds III a \& b.

\section{5-[(3,4-Dimethoxy-phenyl)-hydrazono]-pyrimidine-2,4,6- trione (III a)}

Red crystal, yield (70\%); mp; $270^{\circ} \mathrm{C}-272^{\circ} \mathrm{C}$; IR (film) 3,317, 3,186 $(\mathrm{NH}), 3,059(\mathrm{CH}$, aromatic) 2,835 ( $\mathrm{CH}$, aliphatic), 1,728, 1,705, 1,654 (broad band, $\mathrm{C}=\mathrm{O}$ ) $\mathrm{cm}^{-1} ;{ }^{1} \mathrm{H}$ NMR (DMSO- $d_{6}$ ) $\delta 3.78\left(\mathrm{~s}, 3 \mathrm{H}, 3-\mathrm{OCH}_{3}\right), 3.81\left(\mathrm{~s}, 3 \mathrm{H} .4 \mathrm{OCH}_{3}\right) 7.02(\mathrm{~d}, 1 \mathrm{H}, J=8.8$ $H z$, phenyl H-5), $7.12\left(\mathrm{dd}, J_{1}=8.8 \mathrm{H}_{\mathrm{z}} J_{2}=2 \mathrm{~Hz}, 1 \mathrm{H}\right.$, phenyl $\left.\mathrm{H}-6\right)$, 7.24 (d, $1 \mathrm{H}, J=2 \mathrm{~Hz}$, phenyl $\mathrm{H}-2), 11.21$ (s, $1 \mathrm{H}, \mathrm{NH}$ pyrimidine), 11.42 (s, 1H, NH pyrimidine), 14.29 (s, $1 \mathrm{H}, \mathrm{NH}-\mathrm{N}=\mathrm{C}) ;{ }^{13} \mathrm{C} \mathrm{NMR}$ $\left(\mathrm{DMSO}-d_{6}\right) \delta 56.11,56.23,101.39,109.45,112.72,116.34$,
135.37, 148.02, 150.09, 150.26, 160.45, 162.72; Anal. Calcd for $\mathrm{C}_{12} \mathrm{H}_{12} \mathrm{~N}_{4} \mathrm{O}_{5}: \mathrm{C}, 49.32 ; \mathrm{H}, 4.14 ; \mathrm{N}, 19.17$. Found: $\mathrm{C}, 49.40 ; \mathrm{H}, 4.10$; $\mathrm{N}, 19.30$

\section{5-[(3,5-Dichloro-phenyl)-hydrazono]-pyrimidine-2,4,6-trione (III b)}

Red crystal, yield $(75 \%) ; \mathrm{mp} ; 280^{\circ} \mathrm{C}-282^{\circ} \mathrm{C}$; IR (film) 3,396, 3,232 $(\mathrm{NH}), 3,089(\mathrm{CH}$, aromatic), 2,900 ( $\mathrm{CH}$ aliphatic), 1,739, 1,706, 1,654 (3 C=O) cm ${ }^{-1}$; ${ }^{1} \mathrm{H}$ NMR (DMSO-d $) \delta 7.36(\mathrm{~s}$, 1H, phenyl H-4), 7.63-7.64 (m, 2H, phenyl H-2,6), 11.39 (s, 2H, $2 \mathrm{NH}), 13.76(\mathrm{~s}, 1 \mathrm{H}, \mathrm{NH}-\mathrm{N}=\mathrm{C}) ;{ }^{13} \mathrm{C}$ NMR (DMSO- $\left.d_{6}\right) \delta 115.61$, $120.02,124.82,135.47,144.55,150.10,160.14,161.92$; Mass spectra, $[\mathrm{M}]^{+}=299,14 \%$; Anal. Calcd for $\mathrm{C}_{10} \mathrm{H}_{6} \mathrm{Cl}_{2} \mathrm{~N}_{4} \mathrm{O}_{3}: \mathrm{C}$, 39.89; H, 2.01; N, 18.61. Found: C, 40.00; H, 2.20; N, 18.60.

\section{General procedure for synthesis of compound IV a and b}

The mixture of sodium ethoxide solution (sodium $0.03 \mathrm{~mol}$, absolute ethanol $20 \mathrm{ml})$, compound II a/II b $(0.01 \mathrm{~mol}$, absolute ethanol $20 \mathrm{ml})$, and thiourea $(0.01 \mathrm{~mol}$, absolute ethanol $10 \mathrm{ml}$ ) was heated under reflux for 6 hours. The hot water (40 $\mathrm{ml}$ ) was added to the reaction mixture, then enough amount of $\mathrm{HCl}$ was added until the reaction mixture became acidic to litmus paper and kept in refrigerator for 4 hours. The formed precipitate was filtered, washed with cold water, dried, and crystallized from ethanol to afford the corresponding compounds IV a \& b.

\section{5- [ (3, 4-Dimethoxy-phenyl)- hydrazono $]-2$ - thioxo- dihydropyrimidine-4,6-trione (IV a)}

Red crystal, yield (60\%); mp $264^{\circ} \mathrm{C}-266^{\circ} \mathrm{C}$; IR (film) 3,471, 3,278 $(\mathrm{NH}), 2,900$ (CH aliphatic ), 1,712, 1,670 (broad band, $\mathrm{C}=\mathrm{O}$ ) $\mathrm{cm}^{-1}$; ${ }^{1} \mathrm{H}$ NMR (DMSO- $\left.d_{6}\right) \delta 3.39\left(\mathrm{~s}, 3 \mathrm{H}, 3-\mathrm{OCH}_{3}\right)$, $3.40\left(\mathrm{~s}, 3 \mathrm{H} .4-\mathrm{OCH}_{3}\right) 7.42(\mathrm{~d}, 1 \mathrm{H}, J=12.8 \mathrm{~Hz}$, phenyl H-5) , 7.53$7.57(\mathrm{~m}, 1 \mathrm{H}$, phenyl H-6), 7.67 (s, 1H, phenyl H-2), 12.51(s, $1 \mathrm{H}, \mathrm{NH}$ pyrimidine), $12.65(\mathrm{~s}, 1 \mathrm{H}, \mathrm{NH}$ pyrimidine), $13.87(\mathrm{~s}, 1 \mathrm{H}$, $\mathrm{NH}-\mathrm{N}=\mathrm{C}$ ) $;{ }^{13} \mathrm{C}$ NMR (DMSO- $d_{6}$ ) $\delta 40.36,40.57,115.57,120.75$, 128.92, 129.69, 135.42, 135.49, 144.37, 158.51, 159.81,178.17 ; MASS M, $308=8.44 \%$ Anal. Calcd for $\mathrm{C}_{12} \mathrm{H}_{12} \mathrm{~N}_{4} \mathrm{O}_{4} \mathrm{~S}: \mathrm{C}, 46.75 ; \mathrm{H}$, 3.92 ; N, 18.17, Found: C, 46.50; H, 4.00; N, 18.20.

\section{5-[(3,5-Dichloro-phenyl)-hydrazono]-2-thioxo-dihydro-} pyrimidine-4,6-dione (IV b)

Dark crystal, yield, (55\%); mp $272^{\circ} \mathrm{C}-274^{\circ} \mathrm{C}$; IR (film) 3,475, 3,151 $(\mathrm{NH}), 3,074(\mathrm{CH}$, aromatic $), 2,881(\mathrm{CH}$, aliphatic $)$, $1,755,1,697,1,654(\mathrm{C}=\mathrm{O}) \mathrm{cm}^{-1} ;{ }^{1} \mathrm{H}$ NMR (DMSO- $\left.d_{6}\right) \delta 7.35(\mathrm{~s}$, $1 \mathrm{H}$, phenyl H-4) 7.63 (s, 2H, phenyl H-2,6), 12.60, 12.65 (s, H, $\mathrm{NH}), 12.67(\mathrm{~s}, 1 \mathrm{H}, \mathrm{NH}-\mathrm{N}=\mathrm{C}) ;{ }^{13} \mathrm{C} \mathrm{NMR}\left(\mathrm{DMSO}-d_{6}\right) \delta 115.90$, 120.70, 125.20, 135.48, 144.38, 159.11, 178.15; Anal. Calcd for $\mathrm{C}_{10} \mathrm{H}_{6} \mathrm{Cl}_{2} \mathrm{~N}_{4} \mathrm{O}_{2} \mathrm{~S}: \mathrm{C}, 37.87 ; \mathrm{H}, 1.91 ; \mathrm{N}, 17.67$. Found: C, 37.90; $\mathrm{H}, 1.90 ; \mathrm{N}, 17.80$.

\section{Bacteria}

As listed in Table 1, most of the microorganisms are ATCC or LMG standard isolates and were kindly provided by Microbiology and Immunology Department, Faculty of Pharmacy, Beni-Suef University. Some non-standard lab isolates were isolated and characterized using different microbiological media.

Bacillus sp. was isolated from pus swab by growing on nutrient agar for 24 hours. Suspected diffused colonies with 
white opaque color were subjected to Gram stain and spore stains to confirm the characteristic shape of Bacillus sp. and Sarcina lutea that were isolated from food samples by streaking on Brain heart agar plates and characterizing the yellow color colonies of Sarcina lutea confirmed by Gram stain and microscopically examined to characterize the tetrades cocci arrangement of these bacteria. All bacteria were stored in $30 \%$ Glycerol in $-80^{\circ} \mathrm{C}$.

\section{Antibacterial activity}

The minimum inhibitory concentration (MIC) using the agar dilution method was used for evaluation of antibacterial activity of the new compounds according to reported methods (Sader et al., 2013, Tarek et al., 2014). The results are presented in Table 2.

Table 1. The bacteria used for drug screening.

\begin{tabular}{lc}
\hline Type of microorganism & Code \\
\hline Escherichia coli & ATCC 25922 \\
Enterococcus faecalis & V583 ATCC 700802 \\
Pseudomonas aeruginosa & ATCC 9507 \\
Staphylococcus aureus & ATCC 43300 \\
Sarcina lutea & Lab isolate \\
Salmonella typhi & Lab isolate \\
Bacillus subtilis & Lab isolate \\
\hline
\end{tabular}

\section{Molecular modeling studies}

In this docking study, the Molecular Operating Environment (MOE, Version 2010.08, Chemical Computing Group Inc., Montreal, Quebec, Canada) was used in the docking experiments. The crystal structures of Glucosamine-6-phosphate bound at Glucosamine-6-phosphate synthase enzyme (PDB: ID 2VF5) was obtained from RCSB Protein Data Bank. The docking studies were performed according to reported methods (Abdelgawad et al., 2018).

Docking of the co-crystallized ligand should be carried out to study the scoring energy (s), root mean, and amino acid interactions. Docking was performed using the London Dg force and refinement of the results was done using force field energy. The docking for IV $b$ was achieved via their $3 \mathrm{D}$ structure. The hydrogen bond and interactions with amino acids are presented in Table 3.

\section{RESULTS AND DISCUSSION}

\section{Chemistry}

The new compound II a was prepared through diazocoupling of dimethoxyaniline with the active methylene of diethyl malonate using sodium acetate as a base (Abdelgawad et al., 2018). The ${ }^{1} \mathrm{HNMR}$ of II a showed quartet and triplet peak of ethyl group and also the IR spectrum showed two carbonyl groups as a result from the intramolecular hydrogen bond (Fig. 2).

Table 2. The minimum inhibitory concentration (MIC) of samples against different bacteria $(\mu \mathrm{g} / \mathrm{ml})$ *

\begin{tabular}{cccccccc}
\hline & \multicolumn{3}{c}{ Gram-negative bacteria } & \multicolumn{4}{c}{ Gram-positive bacteria } \\
\hline Compound no. & $\begin{array}{c}\text { Salmonella } \\
\text { typhi }\end{array}$ & $\begin{array}{c}\text { Pseudomonas } \\
\text { aeruginosa }\end{array}$ & E.coli & $\begin{array}{c}\text { Bacillus } \\
\text { subtilis }\end{array}$ & $\begin{array}{c}\text { Sarcina } \\
\text { lutea }\end{array}$ & $\begin{array}{c}\text { Staphylococcus } \\
\text { aureus }\end{array}$ & $\begin{array}{c}\text { Enterococcus } \\
\text { faecalis }\end{array}$ \\
\hline III a & $>200$ & $>200$ & $>200$ & $>200$ & $>200$ & $>200$ & $>200$ \\
III b & $>200$ & $>200$ & $>200$ & $\leq 12.5$ & $\leq 12.5$ & $>200$ & $>200$ \\
IV a & $>200$ & $>200$ & $>200$ & $>200$ & $>200$ & $>200$ & $>200$ \\
IV b & $>200$ & $\leq 12.5$ & $>200$ & $\leq 12.5$ & $\leq 12.5$ & $\leq 12.5$ & $\leq 12.5$ \\
Cefotaxime & 0.7 & 6.25 & 0.7 & 50 & 0.7 & 1.5 & $>200$ \\
Ampicillin & 6.25 & $>200$ & 6.25 & 6.25 & 0.7 & 0.7 & 1.5 \\
\hline
\end{tabular}

Table 3. Interaction between ligand and compound IV $\mathrm{b}$ with receptor.

\begin{tabular}{|c|c|c|c|c|c|}
\hline \multirow{2}{*}{$\frac{\text { Compound no. }}{\text { IVb }}$} & \multirow{2}{*}{$\frac{\text { Affinity Kcal/mol }}{-18.50}$} & \multirow{2}{*}{$\begin{array}{c}\text { No. of Hydrogen bonds } \\
4\end{array}$} & \multicolumn{2}{|c|}{ Distance $(\AA)$ from main residue } & \multirow{2}{*}{$\begin{array}{c}\text { Functional group } \\
\mathrm{C}=\mathrm{O}\end{array}$} \\
\hline & & & Ser401 & 2.21 & \\
\hline & & & Lys603 & 2.55 & $\mathrm{C}=\mathrm{O}, \mathrm{NH}$ \\
\hline & & & Val399 & 2.38 & $\mathrm{NH}$ \\
\hline \multirow[t]{8}{*}{ Ligand } & -15.39 & 9 & Ala602 & 2.75 & $\mathrm{NH}$ \\
\hline & & & Val399 & $2.46,2.52$ & $\mathrm{NH}, \mathrm{OH}$ \\
\hline & & & Thr302, & 3.41 & $\mathrm{OH}$ \\
\hline & & & Gln348 & 2.11 & $\mathrm{P}=\mathrm{O}$ \\
\hline & & & Ser303 & 3.15 & $\mathrm{P}=\mathrm{O}$ \\
\hline & & & Ser349 & 3.20 & $\mathrm{P}-\mathrm{O}$ \\
\hline & & & Ser347 & 2.22 & $\mathrm{P}-\mathrm{O}$ \\
\hline & & & Thr352 & 3.21 & P-O \\
\hline
\end{tabular}


The compounds III a \& b and IV a \& b were synthesized through cyclization of diethyl malonate moiety with urea or thiourea in presence of sodium ethoxide (Abdelgawad et al., 2017). The confirmation of the pyrimidinone III a \& b or thiopyrimidinone IV a \& b was done by NMR. The disappearance of ethyl groups peaks and appearance of $\mathrm{NH}$ groups peaks in ${ }^{1} \mathrm{HNMR}$ spectrum confirm the structure of compounds III a \& b and IV a \& b.

\section{Antibacterial screening}

Results were recorded in terms of MIC, which is the lowest concentration of an antibacterial agent causing almost complete inhibition of growth or giving no visible growth (Table 2). Four new synthesized azo-compounds were screened for antibacterial activity and IV b shown good activities against Gram-positive microorganisms; Sarcina lutea, Staphylococcus aureus, Bacillus subtilis, and Enterococcus faecalis; and Gramnegative microorganisms; Pseudomonas aeruginosa; III b showed good activity against only Gram-positive microorganisms; Sarcina lutea and Bacillus subtilis; (Table 2).

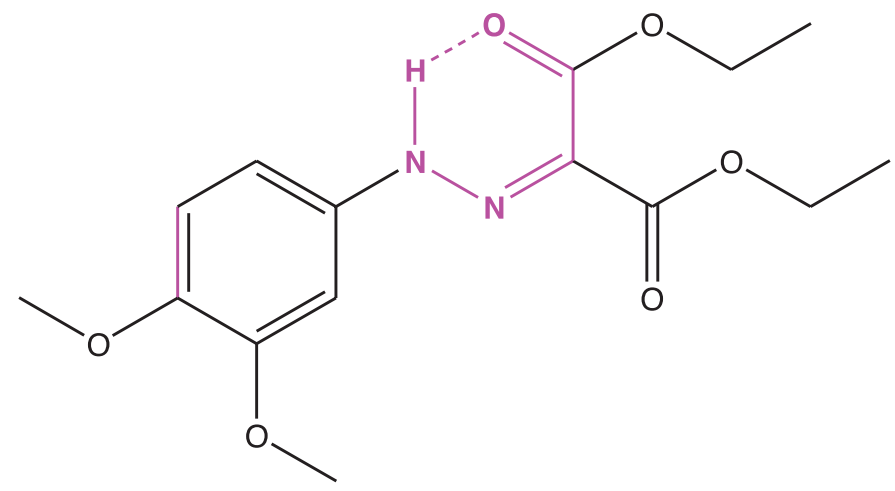

Figure 2. The intramolecular H-bond of II a.

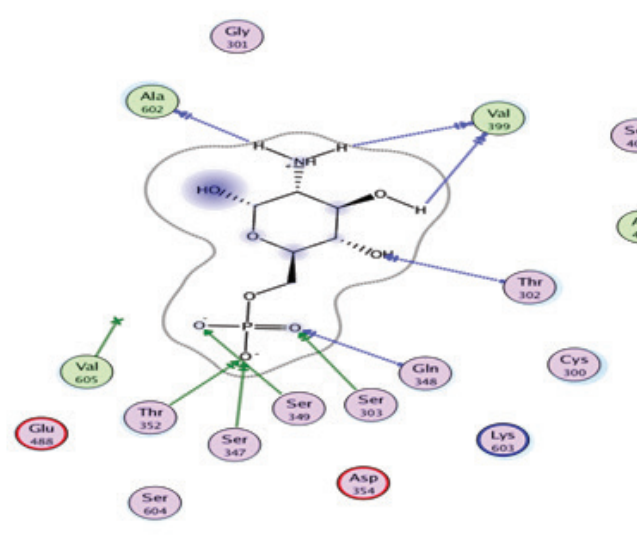

(A)
All tested compounds and controls were used in a final concentration ranging from $(200 \mu \mathrm{g} / \mathrm{ml}-0.7 \mu \mathrm{g} / \mathrm{ml})$. Incubation temperature was $37^{\circ} \mathrm{C} \pm 1^{\circ} \mathrm{C}$ for 24 hours.

\section{Molecular docking study}

To detect the mechanism of action of the newly synthesized target azo-compounds, these compounds were subjected to a molecular docking study using Glucosamine-6phosphate synthase enzyme. This work was performed using (MOE, 2010, Version 8, Chemical Computing Group Inc., Montreal, Quebec, Canada) as a software of choice used in the docking experiments. In this study, the most active azocompounds IV $\mathrm{b}$ were docked into the MurA-F binding site to confirm the ability of the novel candidates to act as antibacterial agents. Glucosamine-6-phosphate synthase enzyme in complex with glucosamine-6-phosphate as a ligand was obtained from protein data bank with codes (PDB: ID 2VF5). Glucosamine6-phosphate was redocked into Glucosamine-6-phosphate synthase with a score energy $(\mathrm{S})=-15.39 \mathrm{kcal} / \mathrm{mol}$. Ala602, Val399, Thr302, Gln348, Ser303, Ser349, Ser347, and Thr352 amino acids were responsible for nine hydrogen bonding interactions with $-\mathrm{NH}_{2},-\mathrm{OH}$, and $-\mathrm{PO}_{4}$ groups (Fig. 3).

The docking results, including the energy associated with intermolecular interactions (affinity in $\mathrm{kcal} / \mathrm{mol}$ ) obtained upon computational docking for the most active compound IV $b$ and Glucosamine-6-phosphate within Glucosamine6-phosphate synthase active site and hydrogen bonding interactions between the amino acid residues and functional groups of compounds are shown in Table 2. From these results, compound IV b revealed the best docking score $(-18.50 \mathrm{kcal} /$ $\mathrm{mol}$ ), it showed three hydrogen bonding interactions; (i) $\mathrm{OCH}_{3}$ with Ser303 (2.55 $\AA$ ), (ii) $\mathrm{OCH}_{3}$ with $\mathrm{Gln} 348$ (2.11 $\AA$ ), and (iii) NH with Glu488 (2.32 Å) (Fig. 4).

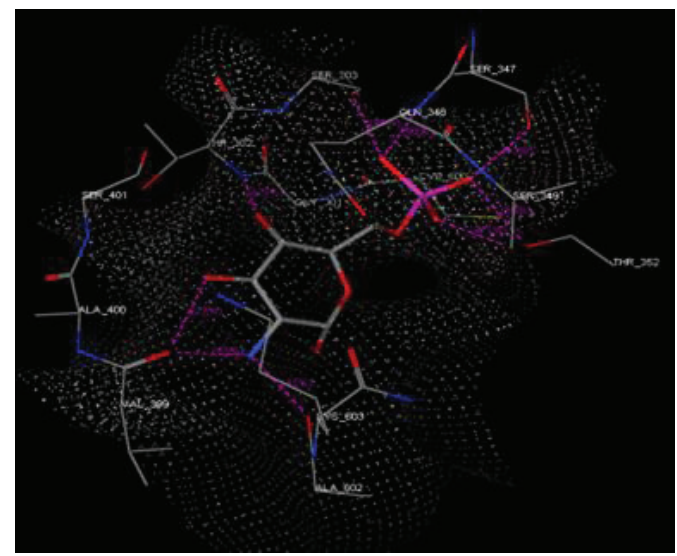

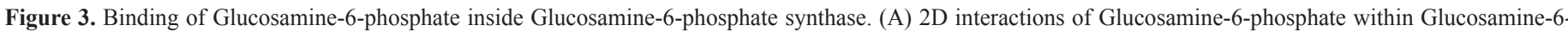

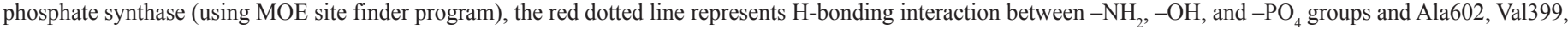
Thr302, Gln348, Ser303, Ser349, Ser347, and Thr352 amino acids. (B) 3D interactions of Glucosamine-6-phosphate. 


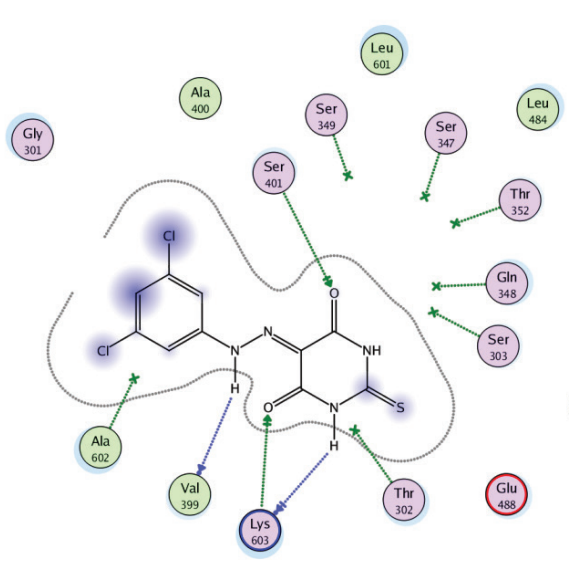

(A)

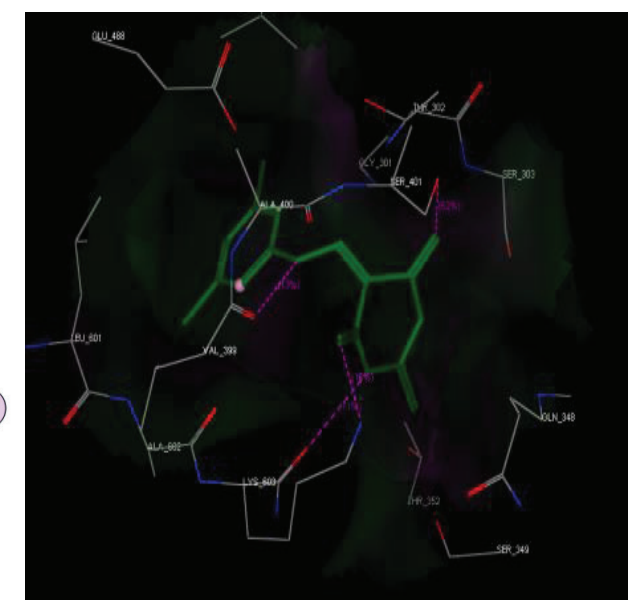

(B)

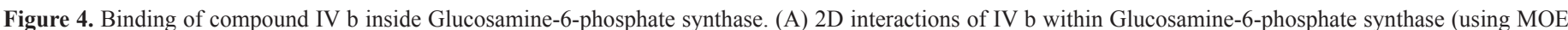

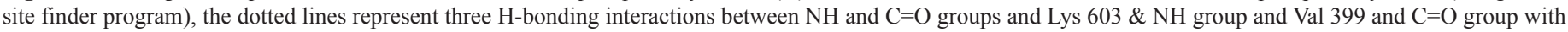
Ser 401. B) 3D interactions of IV b with Glucosamine-6-phosphate synthase.

\section{CONCLUSION}

The new pyrimidinone III a \& $\mathrm{b}$ and thiopyrimidinone IV a \& b, containing disubstituted phenyl, have promising antibacterial activity, especially 3,5-dichlorophenyl. There is compatibility between antibacterial screening result and molecular docking studies of IV b.

The pyrimidine nucleus has no role in the antibacterial activity of the tested compounds, but the meta dichlorobenzene is very important for activity, for example, compound III $b$.

The thiopyrimidine ring increases the spectrum of antibacterial activity of the new azo-compounds, for example, compound IV b. Our future studies will be concerned on about the change of chloride by another halogen atom, for example, fluoride or bromide to study the effect of halogen atom size on the activity of the azo-compounds and study the effect of new substituent on the antibacterial activity. Also, the newly synthesized compound will be screened for cytotoxic activity.

\section{ACKNOWLEDGMENTS}

The author would like to express appreciation to the staff members of the pharmaceutical chemistry department, Jouf University, KSA for supporting this work. Also, the author would like to thank Dr. Ahmed O. El-Gendy and Dr. Rania B. Baker for helping to complete antimicrobial screening and molecular docking studies of this work.

\section{CONFLICT OF INTEREST}

The author declared that there is no conflict of interest.

\section{REFERENCES}

Abd-El Gawad NM, Georgey HH, Ibrahim NA, Amin NH, Abdelsalam RM. Synthesis of novel pyrazole and dihydropyrazoles derivatives as potential anti-inflammatory and analgesic agents. Arch Pharm Res, 2012; 35(5):807-21.

Abdelgawad MA, Bakr RB, Omar HA. Design, synthesis and biological evaluation of some novel benzothiazole/benzoxazole and/or benzimidazole derivatives incorporating a pyrazole scaffold as antiproliferative agents. Bioorg Chem, 2017; 74:82-90.
Abdelgawad MA, Labib MB, Ali WAM, Kamel G, Azouz AA, EL-Nahass ES. Design, synthesis, analgesic, anti-inflammatory activity of novel pyrazolones possessing aminosulfonyl pharmacophore as inhibitors of COX-2/5-LOX enzymes: histopathological and docking studies. Bioorg Chem, 2018; 78:103-14.

Awadallah FM, Piazza GA, Gary BD, Keeton AB, Canzoneri JC. Synthesis of some dihydropyrimidine-based compounds bearing pyrazoline moiety and evaluation of their antiproliferative activity. Eur J Med Chem, 2013; 70:273-9.

Bakulev VA, Berseneva VS, Belskaia NP, Morzherin YY, Zaitsev A, Dehaen W, Luytenb I, Toppet S. Reactions of 5-mercaptoazoles and pyridine-2-thiones with acetylenic esters. Selectivity of the formation of novel fused thiazin-4-ones and thiazolidin-4-ones. Org Biomol Chem, 2003; 1:134-9.

Bansal S, Bala M, Suthar SK, Choudhary S, Bhattacharya S, Bhardwaj V, Singla S, Joseph A. Design and synthesis of novel 2-phenyl-5-(1,3diphenyl-1H-pyrazol-4-yl)-1,3,4-oxadiazoles as selective COX-2 inhibitors with potent anti-inflammatory activity. Eur J Med Chem, 2014; 80:167-74.

Belal A, Abdelgawad MA. New benzothiazole/benzoxazolepyrazole hybrids with potential as COX inhibitors: design, synthesis and anticancer activity evaluation. Res Chem Intermediat, 2017; 43 (7):3859-72.

Cheng CC, Roth B. Recent progress in the medicinal chemistry of 2,4-diaminopyrimidines. Prog Med Chem 1982; 19:269-331.

Etman HA, Sadek MG, Khalil AGM. Synthesis of some new heterocycles derived from 3-amino-5hydrazinopyrazole dihydrochloride. Res J Pharm Biol Chem Sci, 2015; 6(2):247-54.

Gadhaveb A, Gaikar R, Kuchekar S, Karale B. Synthesis and antimicrobial evaluations of some novel fluorinated chromones and pyrazoles. Indian J Chem, 2015; 54(3):383-90.

Kalluraya B, Isloor AM, Frank PV, Jagadeesha RL. Synthesis and pharmacological activity of 4-(substituted)-2-[4-aryl-hydrazono-3methyl-5-oxo-2-pyrazolin-1-yl]-thiazoles. Indian J Heterocycl Chem, 2004; 13(3):245-8.

Koca M, Servi S, Kirilmis C, Ahmedazade M, Kazaz C, Özbek B, Ötük G. Synthesis and antimicrobial activity of (benzofuran-2-yl) (3-phenyl-3-methylcyclobutyl) ketoxime derivatives. Eur J Med Chem, $2005 ; 40: 1351-8$.

Mallikarjunaswamya C, Malleshab L, Bhadregowda DG, Pintoa O. Studies on synthesis of pyrimidine derivatives and their antimicrobial activity. Arab J Chem, 2017; 10(Supplement 1):S484-90.

Mandha SR, Siliveri S, Alla M, Bommena VR, Bommineni MR, Balasubramanian S. Eco-friendly synthesis and biological evaluation 
of substituted pyrano[2,3-c]pyrazoles. Bioorg Med Chem Lett, 2012; 22:5272-8.

Rahmi K, Metin B, Seckin B, Arslan BG. Synthesis, characterization and antiglaucoma activity of some novel pyrazole derivatives of 5-amino-1,3,4-thiadiazole-2-sulfonamide. Eur J Med Chem, 2010; 45:4769-73.

Sader HS, Flamm RK, Jones RN. Antimicrobial activity of daptomycin tested against Gram-positive pathogens collected in Europe, Latin America, and selected countries in the Asia-Pacific Region. Diagn Microbiol Infect Dis, 2013; 75:417-22.

Saundane AR, Verma VA, Vijaykumar K. Synthesis of some new indolo[2,3-c] isoquinolinyl pyrazoles, -1,3,4-oxadiazoles and their biological activities. Med Chem Res, 2013; 22:3787-93.

Sayed HH, Hashem AI, Yousif NM, El-Sayed WA. Conversion of 3-Arylazo-5-phenyl-2(3H)-furanones into other heterocycles of anticipated biological activity. Arch Pharm Chem Life Sci, 2007; 340:315-9.

Schneider P, Hawser S, Islam K. Iclaprim, a novel diaminopyrimidine with potent activity on trimethoprim sensitive and resistant bacteria. Bioorg Med Chem Lett, 2003; 13(23):4217-21.

Riyadh SM, Farghaly TA, Abdallah MA, Abdalla MM, Abd El-Aziz MR. New pyrazoles incorporating pyrazolylpyrazole moiety: Synthesis, anti-HCV and antitumor activity. Eur J Med Chem, 2010; 45:1042-50.

Supplementary Data. ${ }^{1} \mathrm{HNMR}$ of compounds III a \& b and IV a \& b.
Tarek, N, Hassan HM, AbdelGhani SM, Radwan IA, Hammouda O, El-Gendy AO. Comparative chemical and antimicrobial study of nine essential oils obtained from medicinal plants growing in Egypt. Beni-Suef Univ J Basic Appl Sci, 2014; 3:149-56.

Vinita S, Nitin C, Ajay KA. Significance and biological importance of pyrimidine in the microbial world. Int J Med Chem, 2014; ID 202784:1-32.

Zaini E, Sumirtapura YC, Halim A, Fitriani L, Soewandhi SN. Formation and characterization of sulfamethoxazole-trimethoprim cocrystal by milling process. J Appl Pharm Sci, 2017; 7(12):169-73.

How to cite this article:

Abdelgawad MA. Synthesis and antibacterial evaluation of new azo-pyrimidine derivatives. J Appl Pharm Sci, 2019; 9(S1):009-016.

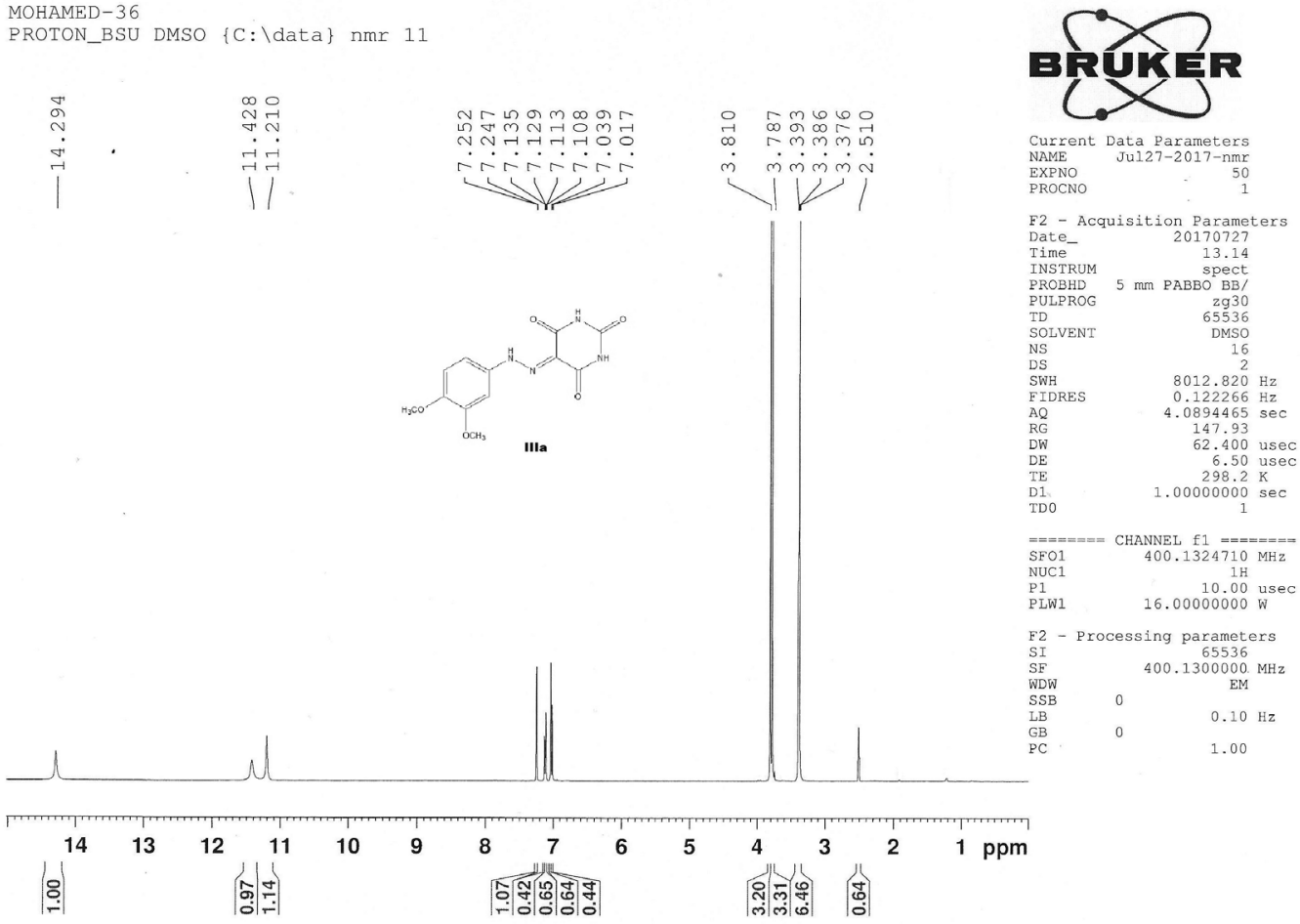

Supplementary Figure 1. ${ }^{1} \mathrm{HNMR}$ of compound IIIa 


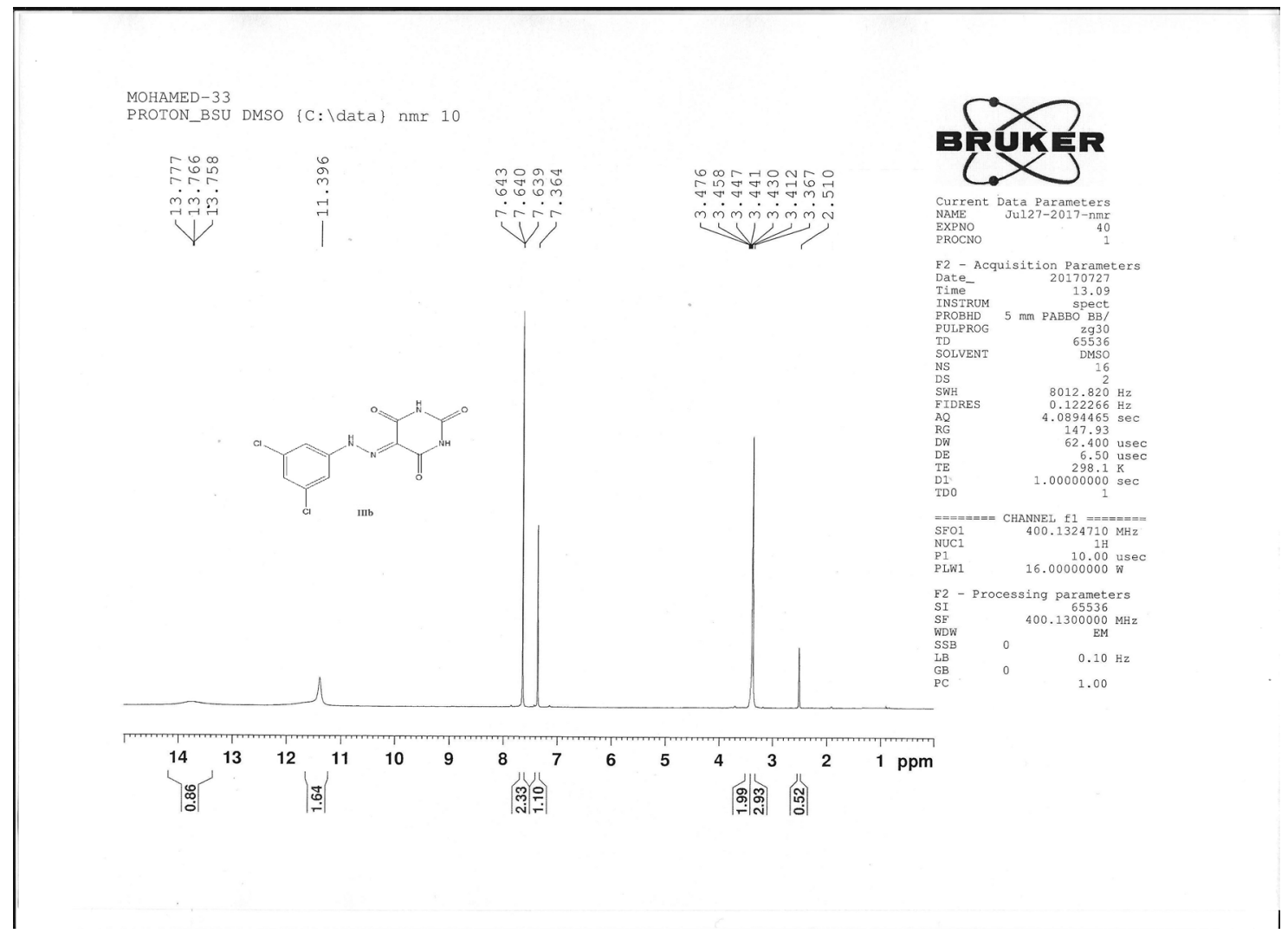

Supplementary Figure 2. ${ }^{1} \mathrm{HNMR}$ of compound IIIb

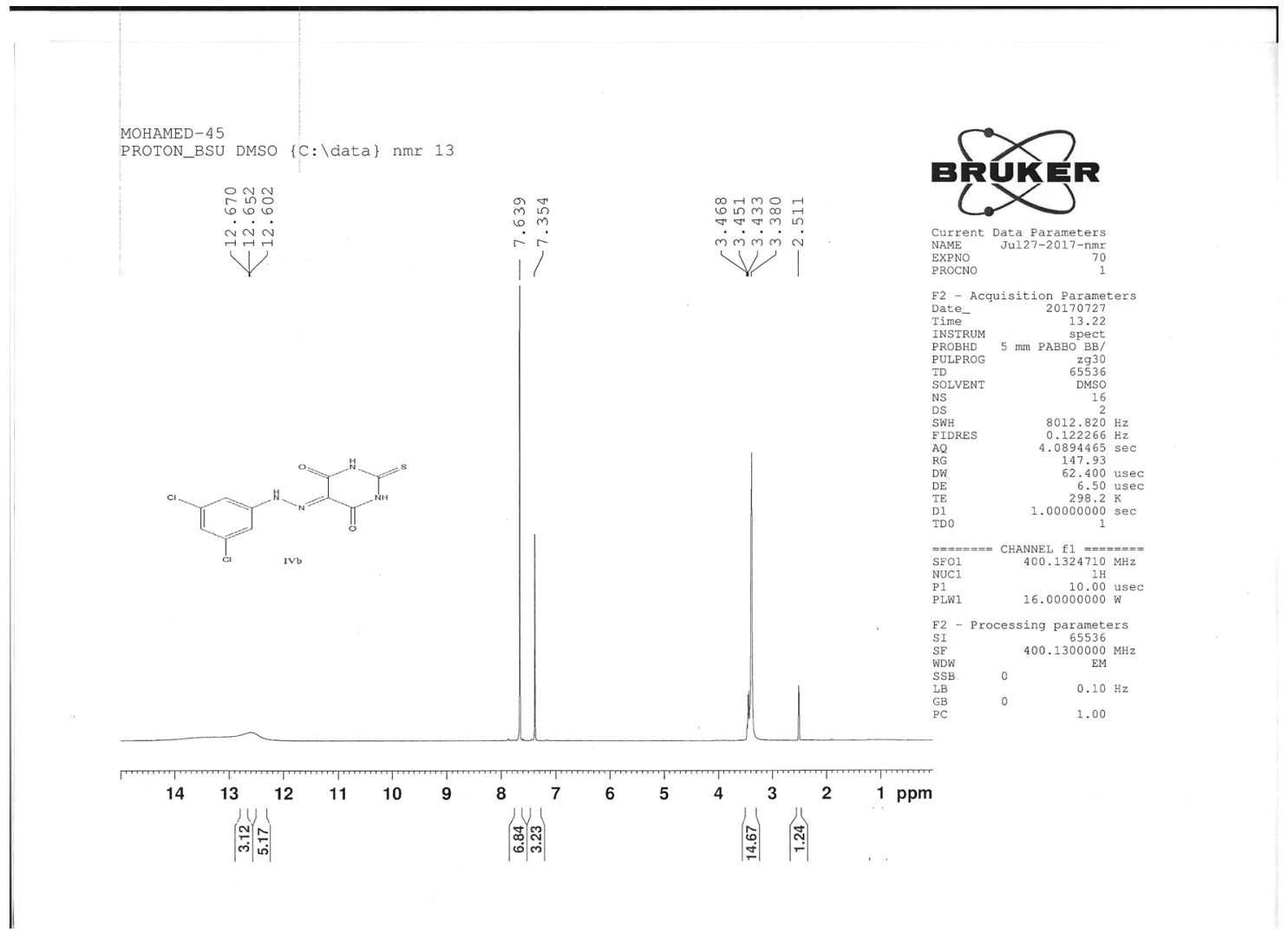

Supplementary Figure 3. ${ }^{1} \mathrm{HNMR}$ of compound IV b 